\title{
A Preliminary Study in Applying Knowledge Framework for Conceptualizing Risk Assessment in Village Government
}

\author{
Deddy Mulyadi ${ }^{1}$, Nur Imam Taufik ${ }^{2}$, Hafid Aditya Pradesa ${ }^{3}$ \\ Polytechnic of STIA LAN Bandung ${ }^{123}$
}

\{deddy.mulyadi@poltek.stialanbandung.ac.id ${ }^{1}$ \}

\begin{abstract}
Contemporary approach to risk had been developed well in many types of organization but still lack of attention about how this could be applied in village government. The purpose of this study is to helps us to understand the emerging concept of knowledge management by exploring the relation between risk and knowledge management. The development of studies and best practices has brought new understanding to how the practice of managing risk in a cross-sectoral institution. But in the other hand the knowledge management perspective is often not used properly in explaining how to conceptualize institutional risk at the village government level. Based on problem that identified in this study, knowledge management theory is presented as a conceptual orientation to institutional risk in village that confronts such attention needed. In addition to furthering a village organization's understanding of major institutional risks, a risk management knowledge framework also provides opportunities for building organizational resilience. This study provides and propose an integrated perspective of knowledge management in village institutional-based organizations. It offers valuable guidelines that can help decision makers consider key issues during a risk assessment of knowledge factors in village institutional management. Outputs of this model could be considered as an extensive assessment report about the risk of knowledge loss in a village organization with suggestions for preservation plans to mitigate its effects in various aspect of village governance.
\end{abstract}

Keywords: Risk Management; Knowledge-based Risk Management; Village Risk.

\section{Introduction}

Nowadays public management in various sectors has led to pressing demands for greater accountability and transparency. In order to strengthen the accountability of the organization, it is deemed necessary to have effective control as part of organizational governance. This ostensibly aims to make organizations and decision makers more responsive to stakeholder demands and expectations (Pradesa, Purba, Priatna, 2021). The quality of the management of village government institutions in Indonesia is currently in the public spotlight. The many 
problems that shackle the world of village governance, ranging from asset and financial management to the low quality of output from work programs and the resulting activities, all bring an unfavorable image to village management in Indonesia. Several things related to management in the village are related to the management of village funds (Martini et al., 2019). with various dynamics of problems that occur, such as misuse of village funds (Adnan, 2019). These various problems indicate that there is a potential for events that have a negative impact on the goals of the village government organization.

Village government agencies as well as other organizations and agencies will always be faced with changes and dynamics in their environment, be it changes that come from within or from outside the organization. Changes in the management of village government institutions can be considered to be autonomous, centralized, so that changes in government regulations all demand serious attention from government agencies. Changes in village government institutions occur so quickly that all these changes are expected to improve the quality of village government institutions in Indonesia. One of the most important things in managing village government organizations is about risk management as part of the control process implemented in village organizations.

Village agencies like other agencies will be faced with risks where this risk hinders the organization in achieving the goals that have been set. Therefore, it is important for village organizations to carry out risk assessments related to the knowledge management theory framework. Risk assessment begins with the process of formulating goals, both agency goals and activity goals. After the objectives are formulated, the process of identifying risks and risk analysis begins. All of these steps will ultimately provide information to leaders, both agency leaders and activity leaders, to take the right approach to minimize the impact of risk.

Local and international practice confirms that risk management is not about avoiding risk, but having the tools to manage it effectively, especially at strategic and operational levels. Each institution must set simple, measurable, achievable and realistic goals in line with the vision and mission of each department, which must precede the risk management identification and assessment process. Organizational risk management is usually based on classical decision theory, where concept of risk at the macro level is perceived as reflecting variations in the distribution of possible outcomes, their likelihood and subjective value (March \& Shapira, 1987).

While Knowledge-based Risk Management has emerged in 2010 (Massingham, 2010) in which could offer a solution to the problems associated with conventional risk management methods. KRM uses "knowledge management tools and techniques to enable individuals to generate deeper insight about the risk management. In particular, the importance of knowledge, especially tacit and skillful ones, is highlighted, as well as the "dark side" of knowledge and its danger to organizations; to also analyze a set of tools and techniques for managing the risks associated with the use of knowledge, namely Knowledge Risk Management (KRM).

The importance of conceptualizing institutional risk in villages with a knowledge framework is to consider several things as follows. First, the development of studies and best practices on risk management in an organization has brought new understanding to how risk management practices are modeled in cross-sectoral institutions. However, it should be noted that on the one hand, the knowledge management perspective is often not or has not been used properly in an effort to explain how to conceptualize institutional risk in an organization, specifically for this article related to the coverage area of knowledge risk management that can be explained specifically at the village government level.

Risk management is an important tool in providing assurance for the achievement of organizational goals. Local and international practice confirms that risk management is not 
about avoiding risk, but having the tools to manage it effectively, especially at strategic and operational levels. Each institution must set simple, measurable, achievable and realistic goals in line with the vision and mission of each department, which must precede the risk management identification and assessment process.

To understand the emerging risk management framework in its context, it is important to understand the institutional or structural forces (laws, regulations, frameworks, policies, offices, processes and procedures) that underpin such changes (Rana et al., 2019). In the context of village government, there are several stakeholders who are recognized and have an important role in risk management institutionally. Pradesa et al., (2021) explain this in the perspective of stakeholder theory as a foothold in the process of identifying institutional risks in village governance. Identifying risk from a stakeholder perspective has led to a more comprehensive understanding of risk management in an organization, especially in village organizations.

By considering various possible problems in village governance that arise in the field, the researcher is interested in reviewing the incidence of mismanagement of village organizations from two perspectives, namely the perspective of internal control and the perspective of knowledge management. The researcher argues that many incidents of mismanagement in village organizations may not simply be caused by errors or lack of control in village governance, but this is also due to lack of knowledge in building village governance.

\section{Literature and Theoretical Review}

\subsection{Risk Management}

Although risk management approaches vary from institution to institution, there are some common challenges and trends that can be identified in their management (Ariff et al., 2014; Mujennah \& Wondabio, 2018). In the context of village government institutions, the application of risk management is still premature, so it is deemed necessary to integrate the risk management framework into strategic planning and decision-making processes in village management. However, maintaining the risk management process and its formal reporting is an important challenge that can provide valuable information on the sustainability process in the implementation of risk management in village government.

In accordance with Government Regulation Number 60 of 2008 concerning the Government Internal Control System (SPIP), the government requires village government to carry out risk management as part of the implementation of the Internal Control System.The problem is, the application of risk management in village government so far is not based on theory and is based on a financial perspective. As a result, the debate on risk-based regulation does not really have a sound basis (Hommel et al., 2016), while the implementation of risk management in a public organization may take longer than three years to actually be implemented (Borraz, 2007; Kong et al., 2018), and because no ERM model in specific organization reported on the highest-level elements (integration), it is difficult to know how long risk management implementation will take in village government.

Village government like other agencies will be faced with risks where this risk hinders the organization in achieving the goals that have been set. Therefore, it is important for village organizations to carry out risk assessments related to the knowledge management theory framework. Risk assessment begins with the process of formulating appropriate goals and objectives, both at the level of agency goals and objectives of activities. After the objectives are formulated, the process of identifying risks and risk analysis begins. All of these steps will ultimately provide information to leaders, both agency leaders and activity leaders, to take the 
right approach to minimize the impact of risk.

\subsection{Village Institutional Risk}

As public officials in village institutions, they have to face several challenges related to knowledge management including the risk of retirement or resignation of officials, knowledge drain, difficulties in recording knowledge, and mapping knowledge. Decision makers need to utilize a risk management system to identify potential knowledge risks.

In order to convert implicit knowledge into explicit organizational knowledge without fear of losing important information, the process must become a strategic object for decision makers to set organizational goals. It seems that organizational decision makers should pay attention to all these risk factors and try to identify, measure and research the risks associated with knowledge management.

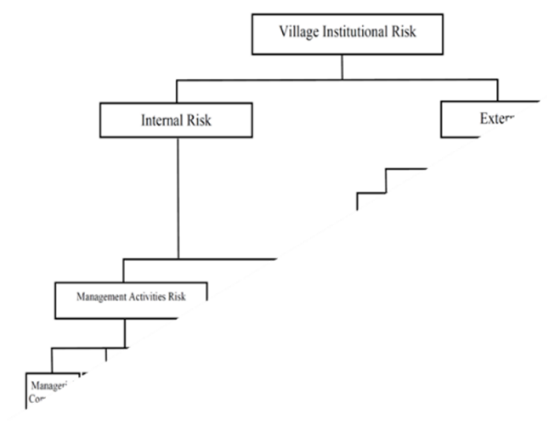

Fig 1. The Hierarchical Institutional Risk in Village breakdown structure

In practice, the purpose of monitoring and regulating village organizations is to reduce institutional risk and maintain organizational stability by identifying vulnerabilities in the knowledge-based management system of a village and implementing policy actions to address those vulnerabilities in a timely manner to prevent crises. In contrast to macroprudential supervision, which requires a "bottom-up" approach that focuses on the governance of village organizations or governance, in turn macroprudential supervision takes a "top-down" approach that focuses on a broad system of village organizational governance in which leaders and officers from village organizations operate and help assess the sources of knowledge-based risk in institutional risk in villages.

The hierarchy above shows that there are potential risks when viewed from management and technical activities in village government organizations. Based on the source of risk, village institutional risk can be considered into two categories, namely internal risk and external risk. Factors in the village government's internal environment that have the potential to be a risk are in two main things, namely management activities risk and technical activities risk.

Internal risk is the risk that arises from the internal environment of the organization, especially from the process of running the organization which has an impact on the continuity of the organization and the achievement of the goals of the organization. External risk is the risk that arises from the external environment of the organization. Internal risks in village government institutions can be viewed from two main points, namely risks related to management activities and technical activities. 
Management activities risk, consists of the following four factors:

a. Managerial competencies. There is the potential for risks to arise in management activities, such as for managerial competencies that do not meet standards.

b. Policies. There is the potential for risks to arise in management activities, such as policies that are not prepared in accordance with standards. This is due to inadequate knowledge of policies.

c. Quality standards. There is a potential risk that there are no quality standards for the processes carried out in village government organizations.

d. Budgeting \& Decision Making. There is a potential risk that there will be discrepancies between the budgeting of the plans that have been prepared by the village government.

e. Technical activities risk, consists of the following four factors:

f. Technology readiness. There is a potential risk of technological readiness in managing village government.

g. Human awareness. There is a potential risk of human awareness of the importance of professionalism in managing village government.

h. System readiness. The potential risk in this system readiness is the unpreparedness of the system in managing village government. The unpreparedness of this system is based on the system infrastructure that still does not meet the standards.

i. Work requirements. The next potential risk related to technical activities is the risk that the work requirements do not or have not met the minimum standards that have been determined.

Both risks in management and technical activities are important to be recognized, identified, and analyzed in relation to the management of village government organizations. When examining how risk and institutional knowledge form the basis for an institutional knowledge risk assessment, it is certainly important to consider how internal and external causes of the organization are identified as risk causes. These internal and external factors can encourage whether increasing or decreasing in tacit and explicit knowledge which will affect how knowledge-based institutional risk assessment is.

In Figure 2, it can be seen that how risk is related to institutional knowledge, and internal and external causal factors are related to institutional knowledge risk assessment.

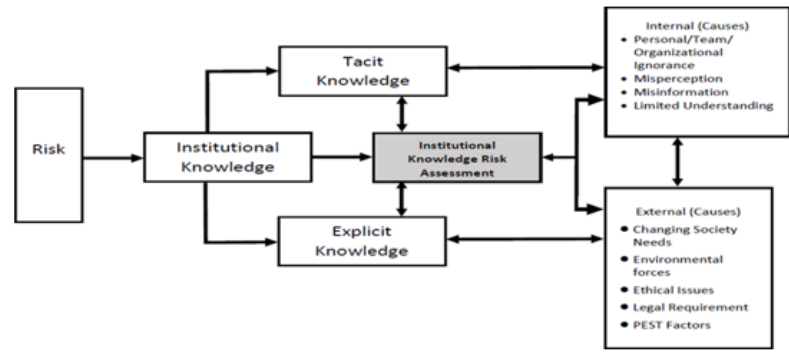

Fig 2. Conceptual Framework for Knowledge Risk Assessment

\section{Discussion}

In practice, the purpose of monitoring and regulating village organizations is to reduce institutional risk and maintain organizational stability by identifying vulnerabilities in the knowledge-based management system of a village and implementing policy actions to address 
those vulnerabilities in a timely manner to prevent crises. In contrast to microprudential supervision, which requires a "bottom-up" approach that focuses on the governance of village organizations or governance, in turn macroprudential supervision takes a "top-down" approach that focuses on a broad system of village organizational governance in which leaders and officers from village organizations operate and help assess the sources of knowledge-based risk in institutional risk in villages.

As village government organizations focus more and more on establishing or finalizing risk management practices, risk officers experience a variety of challenges - from the inception of the risk management process to ensuring that the right decisions and processes are made, to managing the complex engagement of many different functional stakeholders to fulfill the organization's mission, to achieving goals and objectives. Many of the problems encountered when developing or finalizing a risk management approach can be prevented by using sound risk management methodologies and by adhering to regulatory and policy frameworks.

\section{Conclusion}

In practice, the purpose of monitoring and regulating village organizations is to reduce institutional risk and maintain organizational stability by identifying vulnerabilities in the knowledge-based management system of a village and implementing policy actions to address those vulnerabilities in a timely manner to prevent crises. In contrast to microprudential supervision, which requires a "bottom-up" approach that focuses on the governance of village organizations or governance, in turn macroprudential supervision takes a "top-down" approach that focuses on a broad system of village organizational governance in which leaders and officers from village organizations operate and help assess the sources of knowledge-based risk in institutional risk in villages. Understanding that non-optimal governance from the village government can be possible due to the lack of knowledge about risk management, especially in carrying out the risk assessment process.

The proposed conceptual framework is therefore provided as a guide and reference to practitioners and managers to improve village governance and its performance by applying the knowledge management concepts to above propositions, they are:

a. the greater emphasis on knowledge framework will lead to greater level of risk management implementation

b. integrating knowledge framework and risk management will lead to better intermediate action in managing village government

By discussing the theme of knowledge management on the conceptualization of institutional risk in the village, it is believed that risk management is still a problem area within village governance. Many approaches have been suggested for dealing with this problem. This study seeks to demonstrate important ideas about how to apply risk management to village institutions, by accommodating the role of knowledge in the risk assessment process.

This paper has limitations that should be noted. First of all, this research is a conceptual paper in which the survey results are not included and therefore do not add value to this work. Following the above positive perception, hoped in future research aimed to conduct data collection to validate the conceptual framework proposed to address the limitations in the paper. Because in a dynamic environment in village government, seriously bigger efforts need to be continuously developed to perform better in conceptualizing institutional risk in village government. 


\section{References}

[1] Adnan, H. (2019). Implikasi Penyalahgunaan Alokasi Dana Desa Oleh Kepala Desa Terhadap Pemerintahan Desa. Al-Adl : Jurnal Hukum, 11(2), 151. https://doi.org/10.31602/al-adl.v11i2.2122

[2] Ariff, M. S. B. M., Zakuan, N., Tajudin, M. N. M., Ahmad, A., Ishak, N., \& Ismail, K. (2014). A framework for risk management practices and organizational performance in higher education. Review of Integrative Business and Economics Research, 3(2), 422-432.

[3] Borraz, O. (2007). Risk and public problems. Journal of Risk Research, 10(7), 941- 957. https://doi.org/10.1080/13669870701504541

[4] Hommel, U., Li, W., \& Pastwa, A. M. (2016). The state of risk management in business schools. Journal of Management Development, 35(5), 606-622. https://doi.org/10.1108/JMD-08-2014-0088

[5] Kong, Y., Lartey, P. Y., Bah, F. B. M., \& Biswas, N. B. (2018). The Value of Public Sector Risk Management: An Empirical Assessment of Ghana. Administrative Sciences, 8(3), 40. https://doi.org/10.3390/admsci8030040

[6] March, J. G., \& Shapira, Z. (1987). Managerial Perspectives on Risk and Risk Taking.

[7] Management Science, 33(1), 1404-1418. https://doi.org/10.1287/mnsc.33.11.1404

[8] Martini, R., Lianto, N., Hartati, S., Zulkifli, Z., \& Widyastuti, E. (2019). Sistem Pengendalian Intern Pemerintah Atas Akuntabilitas Pengelolaan Keuangan Dana Desa Di Kecamatan Sembawa. Jurnal Akademi Akuntansi, 2(1), 106-123. https://doi.org/10.22219/jaa.v2i1.8364

[9] Massingham, P. (2010). Knowledge risk management: A framework. Journal of KnowledgeManagement, $\quad$ 14(3), 464-485. https://doi.org/10.1108/13673271011050166

[10] Mujennah, L., \& Wondabio, S. (2018). Analisis Sistem Pengendalian Internal dan Implementasi Manajemen Risiko Pada Proses Pengadaan Barang dan Jasa (E- Procurement) Berdasarkan Keputusan Direksi Nomor 305 Tahun 2010 (Studi Kasus Pada PT XYZ (PERSERO) Wilayah Kalimantan Selatan Kalimantan Tenga. Jurnal Spread, 8(1), 31-40.

[11] [10] Pradesa, H. A., Agustina, I., Taufik, N. I., \& Mulyadi, D. (2021). Stakeholder Theory Perspective in the Risk Identification Process in Village Government. Jurnal Ilmu Manajemen Advantage, 5(1), 17-27. https://doi.org/10.30741/adv.v5i1.665

[12] Pradesa, H. A., Purba, C. O., \& Priatna, R. (2021). Menilai risiko dari organisasi yang bertransformasi: pelajaran terbaik untuk penguatan akuntabilitas pendidikan tinggi di Indonesia. Jurnal Akuntabilitas Manajemen Pendidikan, 9(2), 146-158.

[13] Rana, T., Wickramasinghe, D., \& Bracci, E. (2019). New development: Integrating risk management in management control systems - lessons for public sector managers. Public Money and

Management, 39(2), 148-151. https://doi.org/10.1080/09540962.2019.1580921

[14] Adnan, H. (2019). Implikasi Penyalahgunaan Alokasi Dana Desa Oleh Kepala Desa Terhadap Pemerintahan Desa. Al-Adl : Jurnal Hukum, 11(2), 151. https://doi.org/10.31602/al-adl.v11i2.2122

[15] Ariff, M. S. B. M., Zakuan, N., Tajudin, M. N. M., Ahmad, A., Ishak, N., \& Ismail, K. (2014). A framework for risk management practices and organizational performance in higher education. Review of Integrative Business and Economics Research, 3 (2), 422-432.

[16] Borraz, O. (2007). Risk and public problems. Journal of Risk Research, 10 (7), 941- 957. https://doi.org/10.1080/13669870701504541

[17] Hommel, U., Li, W., \& Pastwa, A. M. (2016). The state of risk management in business schools. Journal of Management Development, 35 (5), 606-622. https://doi.org/10.1108/JMD-08-2014-0088

[18] Kong, Y., Lartey, P. Y., Bah, F. B. M., \& Biswas, N. B. (2018). The Value of Public Sector Risk Management: An Empirical Assessment of Ghana. Administrative Sciences, 8(3), 40. https://doi.org/10.3390/admsci8030040

[19] March, J. G., \& Shapira, Z. (1987). Managerial Perspectives on Risk and Risk Taking.

[20] Management Science, 33(1), 1404-1418. https://doi.org/10.1287/mnsc.33.11.1404

[21] Martini, R., Lianto, N., Hartati, S., Zulkifli, Z., \& Widyastuti, E. (2019). Sistem Pengendalian Intern Pemerintah Atas Akuntabilitas Pengelolaan Keuangan Dana Desa Di Kecamatan Sembawa. Jurnal Akademi Akuntansi, 2 (1), 106-123. https://doi.org/10.22219/jaa.v2i1.8364

[22] Massingham, P. (2010). Knowledge risk management: A framework. Journal of Knowledge Management, $14 \quad$ (3), $\quad 464-485$. https://doi.org/10.1108/13673271011050166 
[23] Mujennah, L., \& Wondabio, S. (2018). Analisis Sistem Pengendalian Internal dan Implementasi Manajemen Risiko Pada Proses Pengadaan Barang dan Jasa (E- Procurement) Berdasarkan Keputusan Direksi Nomor 305 Tahun 2010 (Studi Kasus Pada PT XYZ (PERSERO) Wilayah Kalimantan Selatan Kalimantan Tenga. Jurnal Spread, 8(1), 31-40.

[24] Pradesa, H. A., Agustina, I., Taufik, N. I., \& Mulyadi, D. (2021). Stakeholder Theory Perspective in the Risk Identification Process in Village Government. Jurnal Ilmu Manajemen Advantage, 5(1), 17 27. https://doi.org/10.30741/adv.v5i1.665

[25] Pradesa, H. A., Purba, C. O., \& Priatna, R. (2021). Menilai risiko dari organisasi yang bertransformasi: pelajaran terbaik untuk penguatan akuntabilitas pendidikan tinggi di Indonesia. Jurnal Akuntabilitas Manajemen Pendidikan, 9(2), 146-158.

[26] Rana, T., Wickramasinghe, D., \& Bracci, E. (2019). New development: Integrating risk management in management control systems-lessons for public sector managers. Public Moneyand Management, 39(2), 148-151. 
